\title{
Analisis Waktu Pemanasan dan Rasio Komposisi Volume Kerosen dan Minyak Pelumas Pada Proses Upgrading Brown Coal (UBC) Terhadap Nilai Kalor Batubara
}

\author{
Abdi Tunggal ${ }^{* 1}$, Monica Lowinsky ${ }^{2}$, Arizal Aswan ${ }^{3}$, Robert Junaidi ${ }^{4}$, Zurohaina ${ }^{5}$ \\ 1,2,3,4,5 Program Studi Teknik Energi, Jurusan Teknik Kimia \\ Politeknik Negeri Sriwijaya, Indonesia \\ Email: ${ }^{1}$ abditunggal21@gmail.com, ${ }^{2}$ monicalowinsky315@gmail.com
}

Nomor Handphone : 082177-488-677

\begin{abstract}
Abstrak
Pada proses upgrading brown coal (UBC) kadar air pada batubara peringkat rendah dihilangkan dengan pemanasan dalam media minyak yang bahan utamanya adalah minyak ringan dan minyak berat. Adapun metode yang digunakan melibatkan proses preparasi batubara lignit (Brown Coal) meliputi pengecilan ukuran dan pengayakan kemudian proses pemanasan dilakukan pada temperatur $200^{\circ} \mathrm{C}$ dan tekanan 3 Bar dengan memasukan slurry ke tangki pemanas. Pada penelitian ini terdapat variasi waktu pemanasan dan variasi komposisi volume. Pada variasi waktu rasio yang digunakan ialah 1:1:0,5 pada $1 \mathrm{~kg}$ batubara ukuran 20 mesh, 1 liter minyak tanah dan $5 \mathrm{ml}$ minyak pelumas dengan variasi pemanasan $1,5 \mathrm{jam}, 2 \mathrm{jam}, 2,5 \mathrm{jam}, 3 \mathrm{jam}$. Pada variasi rasio perbandingan komposisi, digunakan perbandingan 1:1 yaitu $1 \mathrm{~kg}$ batubara ukuran 60 mesh dan 1 liter minyak tanah dengan variasi minyak pelumas sebesar $0,5 \%, 1 \%, 1,5 \%, 2 \%$ dan $2,5 \%$ berat batubara. Penelitian ini bertujuan untuk mengetahui perbandingan komposisi volume minyak tanah dan minyak pelumas yang paling optimal pada proses Upgrading Brown Coal (UBC) ini. Berdasarkan hasil analisa sebelum dilakukan UBC diketahui bahwa kadar air dari sampel batubara sebesar 19,58\% dan nilai kalor sebesar 3814,7810 Cal/gr kemudian setelah dilakukan proses UBC maka didapatkan peningkatan nilai kalor yang cukup signifikan. Pada variasi waktu ini kadar air berkurang hingga 14,27 dengan nilai kalor 7271,1655 yang terjadi pada waktu pemanasan 3 jam. Sedangkan pada variasi perbandingan komposisi terjadi penurunan kadar air sebesar 8,98 \% dengan kandungan nilai kalor 7479,0601 $\mathrm{Cal} / \mathrm{gr}$ yang terjadi pada rasio $1: 1: 2,5 \%$.
\end{abstract}

Kata kunci: Batubara Lignit, Kadar Air, Nilai Kalor, UBC

\section{Analysis of Heating Time and Volume Composition of Kerosen and Lube Oil in the Upgragding Brown Coal Process (UBC) on the Incrasing of Calorific Value Coal}

\begin{abstract}
In the UBC process, the moisture content in low rank coal is removed by heating in an oil medium whose main ingredients are light oil and heavy oil. The method used involves the preparation of lignite coal (Brown Coal) including size reduction and sieving then the heating process is carried out at a temperature of $200 \mathrm{C}$ and a pressure of 3 Bar by inserting the slurry into the heating tank. In this study, there are variations in heating time and variations in volume composition. In the time variation the ratio used is 1:1:0,5 in $1 \mathrm{~kg}$ of 20 mesh size coal, 1 liter of kerosene and $5 \mathrm{ml}$ of lubricating oil with heating variations of 1.5 hours, 2 hours, 2.5 hours, 3 hours. In the variation of the composition ratio, a 1:1 ratio is used, namely $1 \mathrm{~kg}$ of 60 mesh coal and 1 liter of kerosene with variations in lubricating oil of $0.5 \%, 1 \%, 1.5 \%, 2 \%$ and $2.5 \%$ by weight of coal. . This study aims to determine the ratio of the volume composition of kerosene and lubricating oil which is the most optimal in the Upgrading Brown Coal $(U B C)$ process. Based on the results of the analysis prior to UBC, it is known that the water content of the coal sample is $19.58 \%$ and the calorific value is $3814.7810 \mathrm{Cal} / \mathrm{gr}$ then after the UBC process is carried out, a significant increase in calorific value is obtained. In this time variation, the water content decreased to 14.27 with a calorific value of 7271.1655 which occurred at 3 hours of heating. Meanwhile, in the variation of the composition ratio, the water content decreased by $8.98 \%$ with the calorific value content of 7479.0601 Cal/gr which occurred at a ratio of $1: 1: 2.5 \%$.
\end{abstract}

Keywords: Calorific Value, Inherent Moisture, Lignite or Brown Coal, UBC. 


\section{PENDAHULUAN}

Batubara merupakan salah satu sumber daya energi yang jumlahnya melimpah dibumi, Indonesia sebagai salah satu produsen batubara terbesar di dunia setelah China, USA, India, dan Australia. Jumlah produksi batubara Indonesia pada tahun 2014 mencapai 470,8 juta ton dari jumlah sumber daya yang tersedia sebesar 124,8 miliar ton. Pada tahun 2015, jumlah sumber daya batubara Indonesia mengalami kenaikan sebesar 1,8 miliar ton dengan jumlah cadangan sebesar 32,26 miliar ton. Dari jumlah total sumber daya dan cadangan batubara tersebut sekitar $50 \%$ berada di pulau Sumatera, 49,5\% di pulau Kalimantan, dan sisanya tersebar di pulau Jawa. Sumber daya dan cadangan batubara tersebut didominasi oleh batubara kalori rendah sampai sedang yaitu sebesar 27,11\% merupakan batubara kalori rendah (lignit) dan 63,99\% merupakan batubara kalori sedang (Bituminus). [1]

Teknologi Upgrading Brown Coal (UBC) salah satu metode peningkatan nilai kalor batubara peringkat rendah adalah Upgrading Brown Coal (UBC). UBC pertama kali dikenalkan pada tahun 1990 oleh perusahaan Kobe Steel di Jepang. Sejak 2008, metode ini kemudian mulai dikembangkan menjadi teknologi UBC sekala demo dengan kapasitas 1000 ton/jam yang didirikan di Kalimantan Selatan, Indonesia oleh Japan Coal Energy Center (JCOAL) dan Kementerian ESDM. Dibandingkan dengan teknologi upgrading lainnya, UBC mempunyai keuntungan karena proses dilakukan pada temperatur dan tekanan relatif rendah, yaitu $150-160^{\circ} \mathrm{C}$ pada $0,2-0,3$ Mpa. [2]

Proses UBC dilakukan dengan memanaskan batubara yang telah dicampur dengan campuran minyak tanah dan residu pada suhu $\pm 150^{\circ} \mathrm{C}$ dan tekanan $0,35 \mathrm{MPa}( \pm 3,5 \mathrm{~atm})$. Karena temperatur dan tekanan yang diterapkan cukup rendah, maka pengeluaran tar dari batubara belum sempurna, karenanya perlu ditambahkan zat aditif sebagai penutup permukaan batubara. Untuk proses UBC, sebagai aditif digunakan minyak residu yang merupakan senyawa organik yang beberapa sifat kimianya mempunyai kesamaan dengan batubara. Dengan kesamaan sifat kimia tersebut, minyak berat (heavy oil) yang masuk ke dalam pori-pori batubara akan kering kemudian bersatu dengan batubara. Lapisan minyak ini cukup kuat dan dapat menempel pada waktu yang cukup lama sehingga batubara dapat disimpan di tempat terbuka untuk jangka waktu yang cukup lama. [3]

Pada proses UBC, kandungan moisture dalam batubara peringkat rendah dihilangkan dengan cara pemanasan (dewatering) di dalam media minyak yang bahan utamanya adalah minyak ringan (light oil) minyak berat. Penambahan minyak berat dalam minyak tanah diperlukan untuk menjaga kestabilan kadar air bawaan batubara pasca proses. Sedangkan minyak tanah diperlukan sebagai media dalam proses. Minyak berat tadi sebelumnya ditambahkan dalam jumlah sedikit ke dalam media minyak, kurang lebih $0.5 \mathrm{wt} \%$ (air dried base). Pada saat proses pemanasan berlangsung, air dalam pori-pori batubara keluar, kemudian minyak berat akan teradsorpsi secara selektif di dalam pori-pori tersebut sehingga partikel batubara terlapisi oleh minyak residu yang mengakibatkan air yang keluar dari pori-pori tidak dapat kembali masuk kedalam batubara. Batubara hasil pemanasan kemudian dipisahkan dari minyak dan dikeringkan. Minyak yang telah dipakai dipisahkan dari air (yang berasal dari batubara) berdasarkan perbedaan berat jenis dan dapat digunakan kembali untuk proses berikutnya.

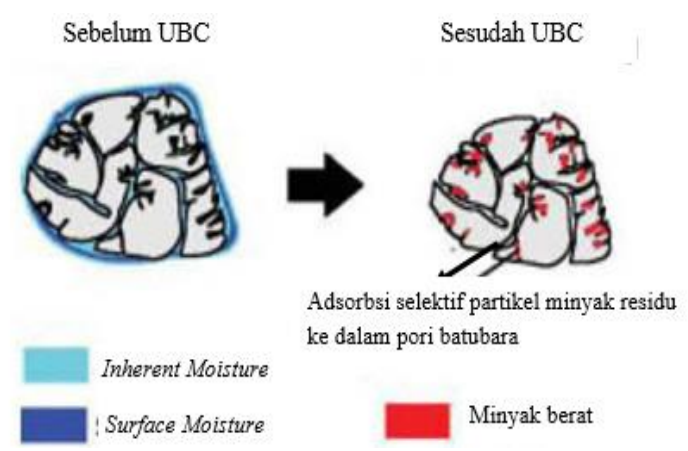

Gambar 1. Batubara Sebelum dan Sesudah dilakukan Upgrading Sumber: tekmira.esdm.go.id

\section{METODE PENELITIAN}

\subsection{Waktu dan Tempat}

Pelaksanaan penelitian rancang bangun alat Upgrading Batubara dengan dilakukan selama 4 bulan yaitu dimulai pada bulan April - Juli 2021 di laboratorium Teknik Energi Jurusan Teknik Kimia Politeknik Negeri Sriwijaya. 


\subsection{Alat dan Bahan}

1. Alat yang digunakan
a. Seperangkat Alat Upgrading Batubara
: 1 Unit
b. Oven
: 1 Unit
c. Furnace
: 1 Unit
d. Bom Calorimeter
: 1 Unit
e. Neraca Analitis
: 1 Unit
f. Grinding Mill/Ball Mill
: 1 Unit
g. Crusher
: 1 Unit
h. Sieving
: 1 Unit
i. Bola Karet
: 1 Buah
j. Beaker Glass $1000 \mathrm{ml}$
: 1 Buah
k. Gelas Piala $15 \mathrm{ml}$
: 1 Buah
1. Corong
: 1 Buah
m. Pipet Ukur
: 1 Buah
n. Wadah
: 1 Buah

2. Bahan yang digunakan
a. Batubara peringkat rendah yang berasal dari PT. Bukit Asam Tbk.
b. Minyak Pelumas (Oli)
: $1000 \mathrm{ml}$
c. Kerosin
d. Air Aquadest
: 5 liter
: Secukupnya

\subsection{Metode Penelitian}

Batubara yang digunakan dalam penelitian ini yaitu batubara sampel yang memiliki kadar inherent moisture yaitu $19,58 \% \%$ dan nilai kalor $3814,7810 \mathrm{Cal} / \mathrm{gr}$.

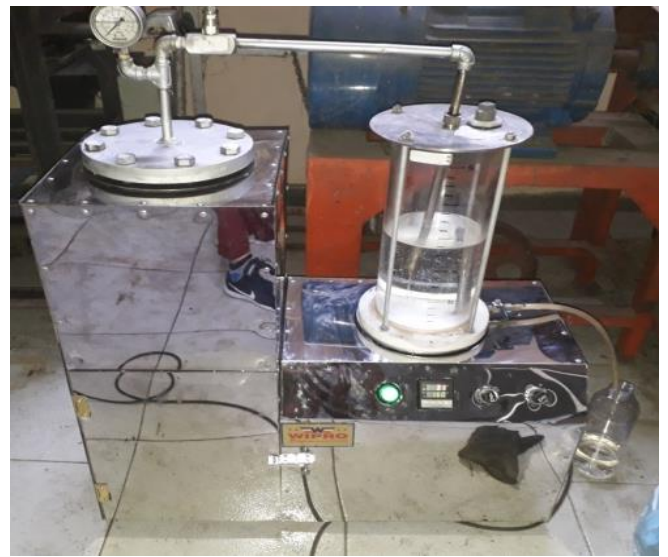

Gambar 2. Alat Upgrading Batubara Tampak 3D

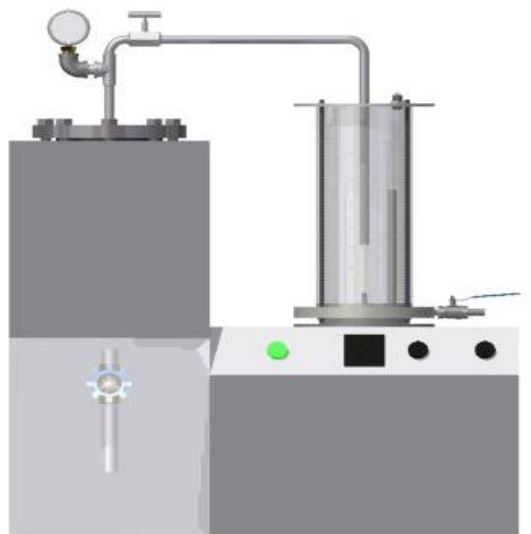

Gambar 3. Alat Upgrading Batubara Tampak Depan 3D 


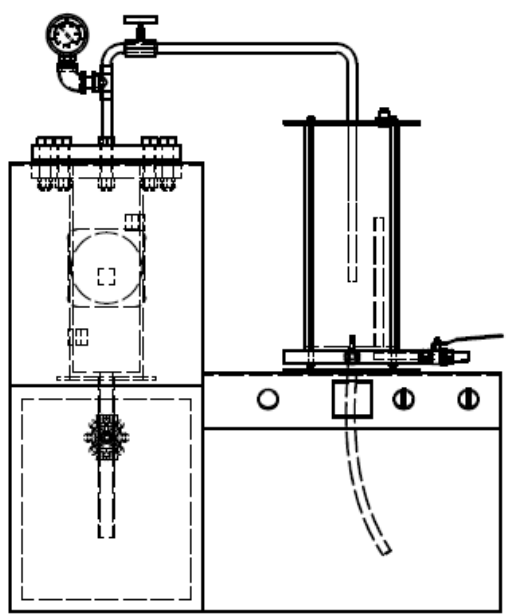

Gambar 4. Alat Upgrading Batubara Tampak Depan

Keterangan :

1. Reaktor

2. Kondenser

3. Panel Kontrol

Tangki pemanas yang dirancang berfungsi sebagai tempat untuk memanaskan slurry (campuran antara batubara, kerosin dan minyak pelumas) sedangkan Kondensor merupakan alat penukar kalor (heat exchanger) yang berfungsi sebagai media terjadinya proses kondensasi uap hasil upgrading batubara

Pengujian yang dilakukan adalah batubara peringkat rendah jenis lignit atau brown coal dilakukan proses preparasi seperti pengecilan ukuran batubara dan pengayakan batubara.Setelah dilakukan preparasi, batubara dengan ukuran 20 mesh dan 60 mesh diumpankan kedalam reaktor pemanas bersamaan dengan kerosin dan minyak pelumas (oli) yang disebut slurry dewatering dengan variasi waktu pemanasan 1,5 jam, 2 jam, 2,5 jam dan 3 jam pada ukuran 20 mesh dan rasio 1:1:0,5\%, serta variasi komposisi volume kerosin dan minyak pelumas dengan rasio $1: 1: 0,5 \%, 1: 1: 1 \%, 1: 1: 1,5 \%, 1: 1: 2 \%$, dan 1:1:2,5\% massa batubara dengan temperatur pemanasan $200^{\circ} \mathrm{C}$ dan tekanan 3 bar selama waktu pemanasan 3 jam. Dengan rasio jumlah volume minyak pelumas $5 \mathrm{ml}, 11 \mathrm{ml}, 17 \mathrm{ml}$, $22 \mathrm{ml}$, dan $28 \mathrm{ml}$.dalam $1000 \mathrm{ml}$ atau 1 liter kerosin. Setelah kondisi operasi tersebut tercapai maka valve dibuka dimana kerosin akan menguap bersamaan dengan inherent moisture menuju kondensor pada keadaan tersebut tekanan operasi akan menurun, oleh karena itu bukaan valve harus dijaga untuk mengatur tekanan tidak menurun lebih dari 3 bar.

Kerosin dan Inherent moisture akan mengalami pemisahan. Sementara batubara yang berada didalam reaktor dilakukan pengeringan selama 3 jam untuk proses oil recovery. Batubara yang telah diproses akan dikeluarkan melalui valve dan dilakukan pengeringan menggunakan oven. Batubara yang sudah kering akan dilakukan analisa proksimat dan nilai kalor untuk mengetahui kualitas batubara tersebut

\subsubsection{Metode Penelitian pada Alat}

a. Analisis Proksimat Analisis ini berdasarkan American Standard for Testing Material (ASTM) D7582-10.

b. Penentuan Nilai Kalor

Nilai kalor ditentukan dengan cara membakar contoh batubara dalam calorimeter bomb pada kondisi standar. Kalor yang dihasilkan dihitung dariperubahan suhu sebelum dan sesudah pembakaran. Cara ini dilakukan berdasarkan ASTM D5865-11a.

\section{HASIL DAN PEMBAHASAN}

\subsection{Pengambilan Sampel}

Lokasi pengambilan sampel batubara yaitu stockpile PT. Bukit Asam Tbk. Pengambilan sampel dilakukan di satu titik saja karena sampel masih akan dilakukan analisis nilai kalor dan kadar air batubara tersebut. Batubara kemudian dilakukan pengkondisian yang disebut sebagai preparasi barubara yaitu pengecilan ukuran (Grinding), pengayakan (Shieving) dan analisa awal sebelum akhirnya dilakukan uji upgrading pada sampel tersebut. 


\subsection{Pengaruh Variasi Waktu Pemanasan}

\section{a. Pengaruh Variasi waktu Terhadap Kandungan Air}

Dari penelitian yang telah dilakukan didapatkan grafik hubungan pengaruh waktu pemanasan terhadap kandungan air yang dapat dilihat pada gambar dibawah ini.

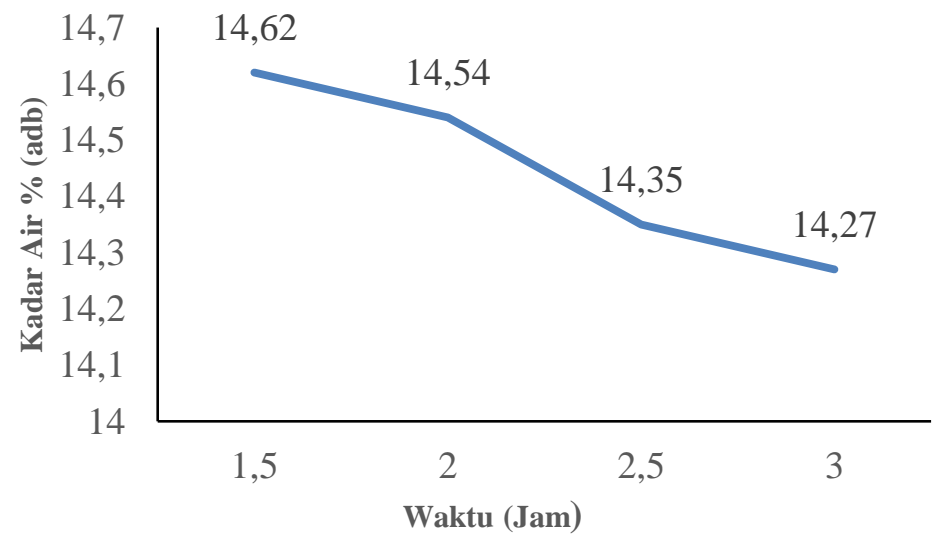

Gambar 5. Grafik Hubungan Pengaruh Waktu Pemanasan Terhadap Kadar air Setelah dilakukan UBC

Dari grafik tersebut telah terjadi penurunan kadar air batubara pada setiap penambahan waktu yang digunakan, dimana nilai kadar air pada sampel sebelum di upgrading sebesar 19,58 kemudian turun hingga mencapai nilai 14,27. Waktu pemanasan menyebabkan proses penguapan semakin maksimal seiring dengan lamanya waktu pemanasan tersebut. produk UBC pada setiap waktu pemanasan batubara berkaitan dengan proses pemanasan dan lamanya proses pemanasan. Pada proses transfer panas terjadi perpindahan panas dari kerosin yang merupakan media transfer panas ke permukaan batubara. Inherrent moisture yang terdapat di dalam pori batubara kemudian menguap dikarenakan perbedaan tekanan uap akibat dari kenaikan suhu dan lamanya waktu pemanasan.

\section{b. Pengaruh Variasi Waktu Terhadap Nilai Kalor}

Dari penelitian yang telah dilakukan didapatkan grafik hubungan pengaruh waktu pemanasan terhadap nilai kalor yang dapat dilihat pada gambar dibawah ini.

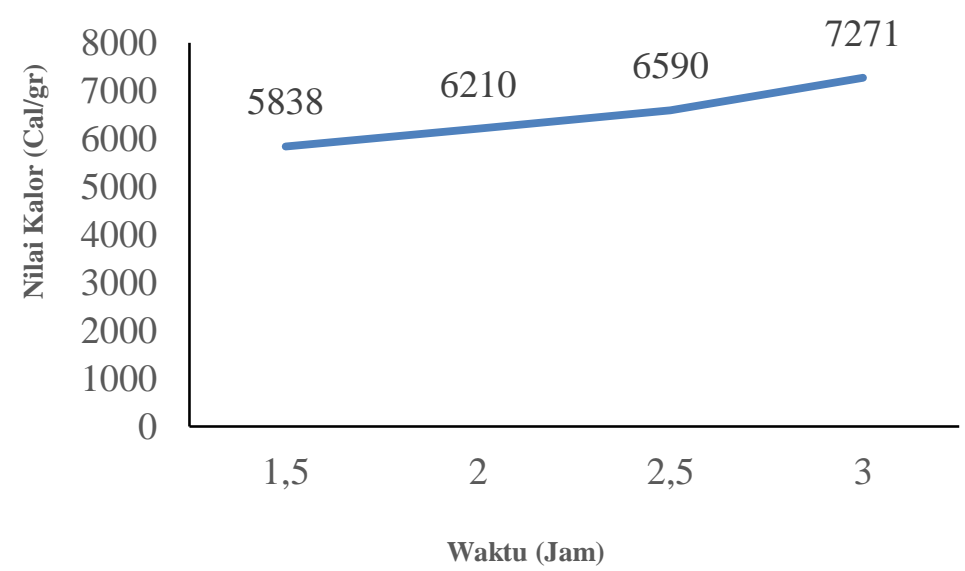

Gambar 6. Grafik Hubungan Pengaruh Waktu Pemanasan Terhadap Nilai kalor setelah dilakukan UBC

Dari grafik diatas dapat dianalisa bahwa nilai kalor dapat dianalisa bahwa semakin lama waktu pemanasan maka akan semakin besar nilai kalor, terjadinya peningkatan nilai kalor pada penambahan waktu proses slurry dipanaskan hal ini terjadi karena dipengaruhi oleh campuran oli sebagai coating agent dimana semakin lama proses pemanasan maka semakin lama interaksi yang terjadi.Adapun pengaruh lama waktu pemanasan menyebabkan proses penguapan air semakin baik dan mengakibatkan sedikitnya 
kadar air.kandungan moisture yang tinggi dapat menurunkan nilai kalor batubara. Apabila nilai moisture meningkat secara otomatis maka nilai kalori pun akan turun, sebaliknya apabila nilai moisture dapat dijaga atau diturunkan maka nilai kalor akan relative stabil bahkan akan meningkat. Peningkatan nilai kalor setelah dilakukannya pencampuran batubara dengan kerosin dan oli dengan variasi waktu pemanasan 1,5 jam dengan nilai kalor 5838,2357 cal/gr, 2 Jam dengan nilai kalor 6210,5685 cal/gr, 2,5 jam dengan nilai kalor 6590,8295 cal/gr, dan 3 Jam dengan nilai kalor 7271,1656 cal/gr.

\section{c. Pengaruh Variasi Waktu Terhadap Kadar Air}

Dari penelitian yang telah dilakukan didapatkan grafik hubungan pengaruh waktu pemanasan terhadap nilai kalor yang dapat dilihat pada gambar dibawah ini.

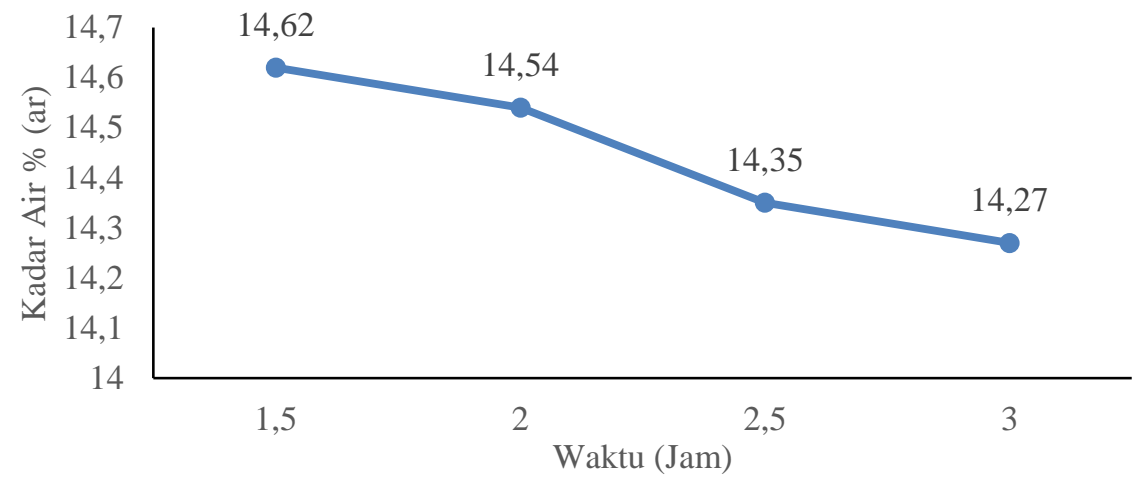

Gambar 7. Grafik Hubungan Pengaruh Waktu Pemanasan Terhadap Kadar Air Setelah dilakukan UBC

Dari keempat sampel hasil analisa kadar air dengan perbedaan waktu pemanasan batubara didapat pula empat nilai inherent moisture (IM) yang berbeda pula. Nilai Inherent Moisture yang paling besar terdapat pada batubara sampel 1 dengan waktu pemanasan 1,5 Jam sebesar 14,62 \% sedangkan untuk nilai Inherent Moisture paling kecil terdapat pada batubara dengan waktu pemanasan telama yaitu 3 Jam $14,27 \%$. Dari grafik tersebut dapat dilihat terjadi penurunan kadar air batubara seiring dengan semakin lamanya waktu pemanasan dimana nilai kadar air sebelum di upgrading sebesar 19,58 \%. Perbedaan nilai inherent moisture produk UBC pada setiap waktu pemanasan batubara berkaitan dengan proses pemanasan dan lamanya proses pemanasan. Pada proses transfer panas terjadi perpindahan panas dari kerosin yang merupakan media transfer panas ke permukaan batubara

\section{d. Pengaruh Variasi Waktu Terhadap Fixed Carbon}

Dari penelitian yang telah dilakukan didapatkan grafik hubungan pengaruh waktu pemanasan terhadap Fixed Carbon kalor yang dapat dilihat pada gambar dibawah ini.

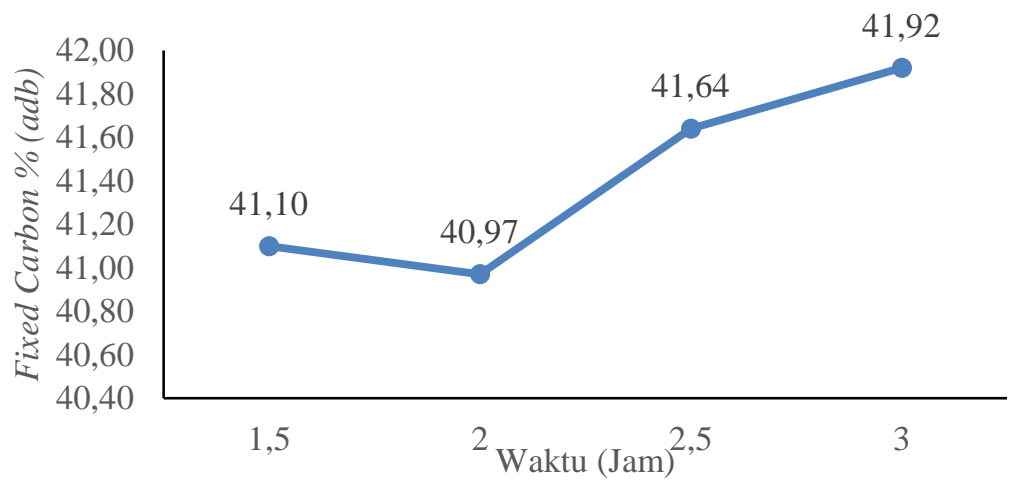

Gambar 8. Grafik Hubungan Pengaruh Waktu Pemanasan Terhadap Fixed Carbon Setelah dilakukan UBC

Dari hasil analisa dapat dilihat nilai kadar fixed carbon paling tinggi ialah batubara dengan waktu pemanasan 2 jam sebesar 41,97\% sedangkan nilai fixed carbon paling kecil ialah batubara dengan waktu 
pemanasan 1 jam sebesar 41.10\%. Tidak menentunya nilai fixed carbon ini dipengaruhi oleh temperatur pemanasan, ukuran batubara, nilai kadar air dan volatile matter karena semakin tingginya kadar air dan kadar volatille matter dapat menyebabkan menurun kadar fixed carbon. Pada batubara terjadi peningkatan kadar karbon dari 41.10 \% menjadi 41,97 \% kemudian menurun kembali menjadi 41,64 \% dan naik lagi menuju $41,97 \%$

e. Pengaruh Variasi Waktu Terhadap Kadar Abu (Ash)

Dari penelitian yang telah dilakukan didapatkan grafik hubungan pengaruh waktu pemanasan terhadap Kadar Abu (Ash) yang dapat dilihat pada gambar dibawah ini.

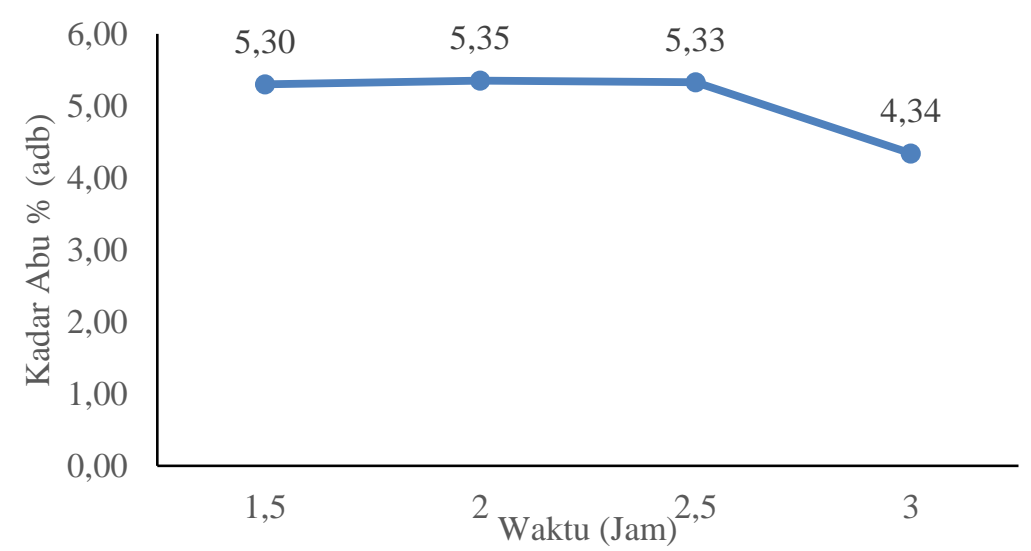

Gambar 9. Grafik Hubungan Pengaruh Waktu Pemanasan Terhadap Kadar Abu (Ash) Setelah dilakukan UBC

Dari hasil analisa didapatkan nilai kadar abu paling tinggi ialah pada waktu pemanasan 2 jam sebesar $5,35 \%$. Sedangkan kadar abu paling rendah terdapat pada batubara dengan waktu pemanasan 3 jam sebesar 4,34\%. Kecenderungan penurunan kadar abu pada batubara disebabkan karena kandungan zat terbang yang tinggi. Telah diketahui bahwa kandungan zat terbang yang tinggi akan lebih mempercepat pembakaran karbon padatnya sehingga proses pembakaran terjadi lebih maksimal. Zat terbang yang diakibatkan dari banyaknya kerosin dan oli yang terserap menambah sifat spontaneous combustible pada batubara.

\section{f. Pengaruh Variasi Waktu Terhadap Volatile Matter}

Dari penelitian yang telah dilakukan didapatkan grafik hubungan pengaruh waktu pemanasan terhadap Volatile Matter yang dapat dilihat pada gambar dibawah ini.

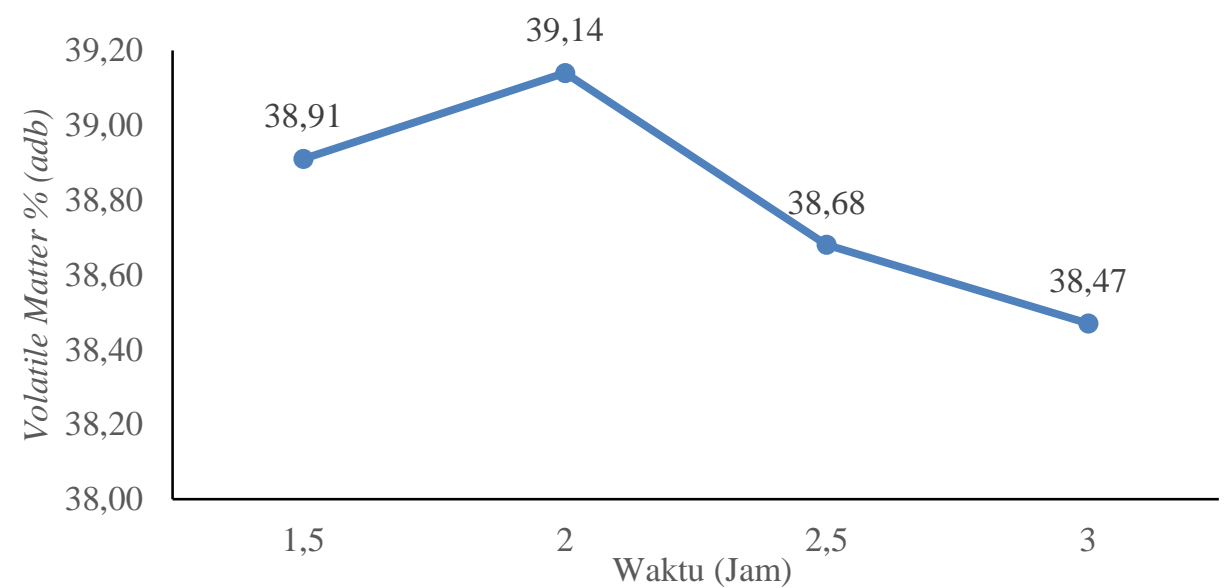

Gambar 10. Grafik Hubungan Pengaruh Waktu Pemanasan Terhadap Volatile Matter Setelah dilakukan UBC 
Dengan adanya proses upgrading ini kandungan nilai zat terbang telah mengalami peningkatan dari sebelum di upgrading. Dari hasil pengujian analisa kadar zat terbang terlihat nilai zat terbang (volatile matter) paling tinggi ialah sampel produk batubara dengan waktu pemanasan selama 2 Jam sebesar $39,14 \%$. Kadar zat terbang ini sudah termasuk dalam batubara jenis sub-bitumius yang berkisar antara $28-45 \%$ (ASTM).

\subsection{Pengaruh Rasio Komposisi}

Proses upgrading batubara peringkat rendah ini bertujuan untuk meningkatkan kualitas batubara dengan cara mereduksi nilai inherent moisture atau kadar lengas tertambat dalam batubara dan meningkatkan nilai kalor batubara. Penelitian ini memfokuskan pendataan pada variasi rasio komposisi volume kerosen dan minyak pelumas $1: 0,5 \%, 1: 1 \%, 1: 1,5 \%, 1: 2 \%, 1: 2,5 \%$ untuk mendapatkan kondisi optimum terhadap peningkatan nilai kalor batubara dan penurunan inherent moisture batubara setelah dilakukan proses Upgrading Brown Coal (UBC). Adapun batubara yang digunakan pada penelitian ini adalah batubara lignit/brown coal yang telah dianalisa terlebih dahulu untuk mengetahui kadar air (inherent moisture), kadar zat terbang (Volatile Matter), kadar abu (Ash), kadar karbon tetap (Fixed Carbon) dan nilai kalor, ukuran batubara yang digunakan 60 mesh, temperatur pemanasan $200^{\circ} \mathrm{C}$ selama 2,5jam dengan waktu pengeringan 3 jam.

\subsection{Analisa Kualitas Batubara Awal sebelum dilakukan upgrading}

Analisa kualitas batubara awal dilakukan untuk mengetahui nilai kalor, kadar air, kadar abu, volatile matter, dan kadar zat terbang antara lain analisa proksimat dan nilai kalori batubara.

\subsection{Desain Penelitian}

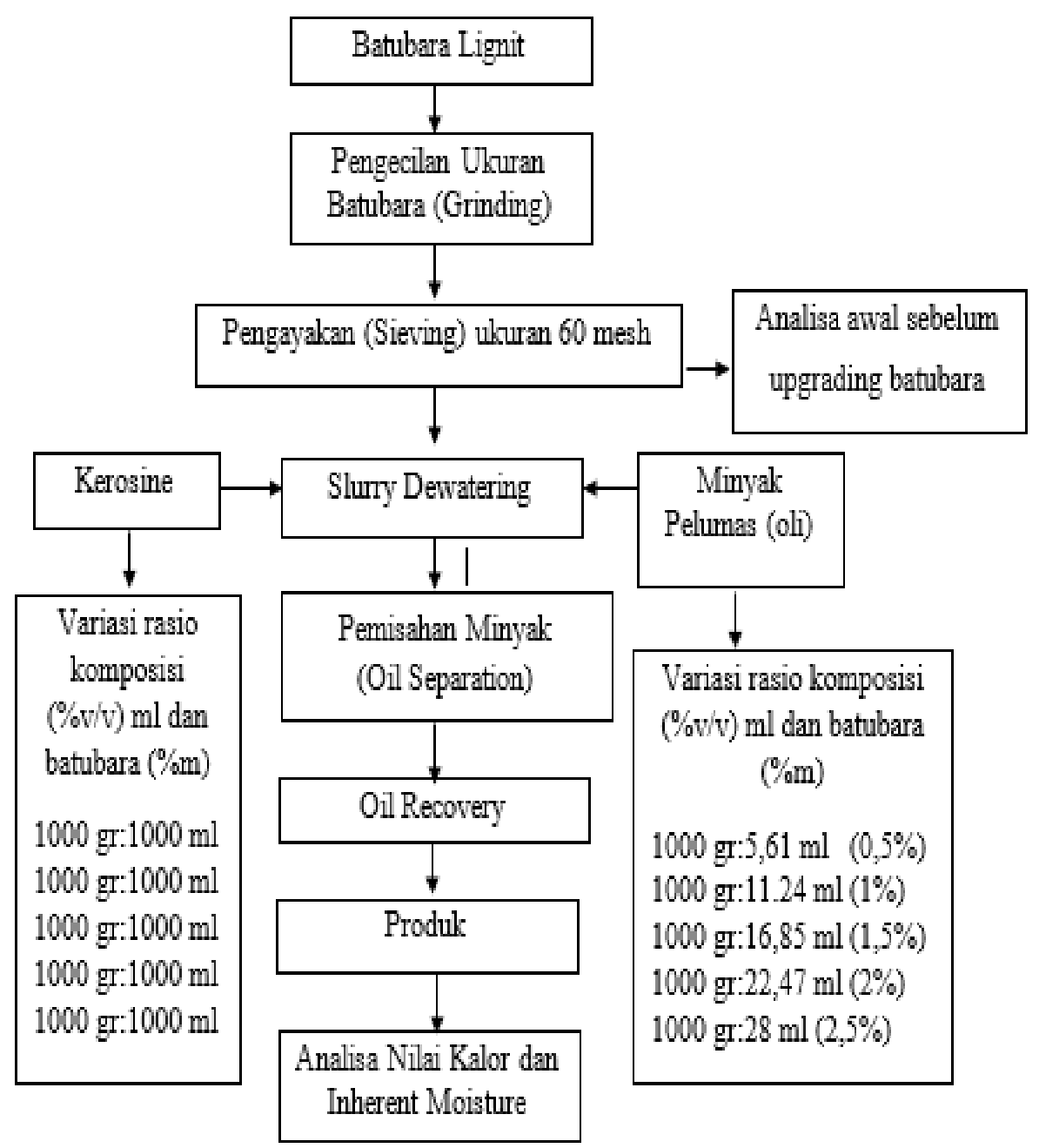

Gambar 11. Diagram Alir Proses Upgrading Brown Coal 


\subsection{Hasil Nilai Kalor Batubara Sebelum dan Setelah dilakukan Upgrading Batubara menggunakan} Standar Benzoat dengan Metode ASTM D5865-11a

Tabel 1. Hasil Nilai Kalor Batubara Sebelum dan Setelah dilakukan Upgrading Batubara menggunakan Standar Benzoat dengan Metode ASTM D5865-11a

\begin{tabular}{ccc}
\hline Rasio Batubara:Kerosin:Oli $(\%)$ & Hasil Uji (Cal/gr) & Keterangan \\
\hline- & 3814,7810 & Sebelum Upgrading \\
$1: 1: 0,5$ & 6290,3176 & Setelah Upgrading \\
$1: 1: 1$ & 6822,8717 & Setelah Upgrading \\
$1: 1: 1,5$ & 7207,1649 & Setelah Upgrading \\
$1: 1: 2$ & 7479,0601 & Setelah Upgrading \\
$1: 1: 2,5$ & 7962,7717 & Setelah Upgrading \\
\hline
\end{tabular}

Sumber: Laboratorium Analisa Batubara Teknik Kimia Politeknik Negeri Sriwijaya, 2021

\subsection{Hasil Analisa Proksimat Batubara Sebelum Upgrading}

Tabel 2. Hasil Analisa Proksimat Batubara Sebelum Upgrading

\begin{tabular}{clcccc}
\hline No & \multicolumn{1}{c}{$\begin{array}{c}\text { Parameter } \\
\text { Analisis }\end{array}$} & Satuan & Standar & Hasil Uji & Metode \\
\hline 1 & Kadar Air & $\%(\mathrm{ar})$ & CRM & 19,58 & ASTM D7582-10 \\
2 & Fixed Carbon & $\%(\mathrm{adb})$ & CRM & 38,12 & ASTM D7582-10 \\
3 & Kadar Abu (Ash) & $\%(\mathrm{adb})$ & CRM & 3,58 & ASTM D7582-10 \\
4 & Volatile Matter & $\%(\mathrm{adb})$ & CRM & 38,71 & ASTM D7582-10 \\
\hline
\end{tabular}

\subsection{Hasil Analisa Proksimat Batubara Setelah Upgrading}

Tabel 3. Rasio Batubara : Kerosin Minyak Pelumas (1:1:0,5\%)

\begin{tabular}{|c|c|c|c|c|c|}
\hline No & $\begin{array}{c}\text { Parameter } \\
\text { Analisis }\end{array}$ & Satuan & Standar & Hasil Uji & Metode \\
\hline 1 & Kadar Air & $\%($ ar) & CRM & 15,26 & $\begin{array}{c}\text { ASTM } \\
\text { D7582-10 }\end{array}$ \\
\hline 2 & Fixed Carbon & $\%(\mathrm{adb})$ & CRM & 40,52 & $\begin{array}{c}\text { ASTM } \\
\text { D7582-10 }\end{array}$ \\
\hline 3 & Kadar Abu (Ash) & $\%(\mathrm{adb})$ & CRM & 5,40 & $\begin{array}{c}\text { ASTM } \\
\text { D7582-10 }\end{array}$ \\
\hline 4 & Volatile Matter & $\%(\mathrm{adb})$ & CRM & 38,83 & $\begin{array}{c}\text { ASTM } \\
\text { D7582-10 }\end{array}$ \\
\hline
\end{tabular}

Sumber: Laboratorium Analisa Batubara Teknik Kimia Politeknik Negeri Sriwijaya, 2021

Tabel 4. Rasio Batubara : Kerosin Minyak Pelumas (1:1:1\%)

\begin{tabular}{cccccc}
\hline No & $\begin{array}{c}\text { Parameter } \\
\text { Analisis }\end{array}$ & Satuan & Standar & Hasil Uji & Metode \\
\hline 1 & Kadar Air & $\%(\mathrm{ar})$ & CRM & 14,69 & ASTM D7582-10 \\
2 & Fixed Carbon & $\%(\mathrm{adb})$ & CRM & 43,84 & ASTM D7582-10 \\
3 & Kadar Abu (Ash) & $\%(\mathrm{adb})$ & CRM & 4,02 & ASTM D7582-10 \\
4 & Volatile Matter & $\%(\mathrm{adb})$ & CRM & 37,46 & ASTM D7582-10 \\
\hline
\end{tabular}


Tabel 5. Rasio Batubara : Kerosin Minyak Pelumas (1:1:1,5\%)

\begin{tabular}{|c|c|c|c|c|c|}
\hline No & $\begin{array}{c}\text { Parameter } \\
\text { Analisis }\end{array}$ & Satuan & Standar & Hasil Uji & Metode \\
\hline 1 & Kadar Air & $\%(\operatorname{ar})$ & CRM & 11,57 & $\begin{array}{c}\text { ASTM } \\
\text { D7582-10 }\end{array}$ \\
\hline 2 & Fixed Carbon & $\%(\mathrm{adb})$ & CRM & 56,46 & $\begin{array}{c}\text { ASTM } \\
\text { D7582-10 }\end{array}$ \\
\hline 3 & Kadar Abu (Ash) & $\%(\mathrm{adb})$ & CRM & 2,97 & $\begin{array}{c}\text { ASTM } \\
\text { D7582-10 }\end{array}$ \\
\hline 4 & Volatile Matter & $\%(\mathrm{adb})$ & CRM & 29,00 & $\begin{array}{c}\text { ASTM } \\
\text { D7582-10 }\end{array}$ \\
\hline
\end{tabular}

Sumber: Laboratorium Analisa Batubara Teknik Kimia Politeknik Negeri Sriwijaya, 2021

Tabel 6. Rasio Batubara : Kerosin Minyak Pelumas (1:1:2\%)

\begin{tabular}{|c|c|c|c|c|c|}
\hline No & $\begin{array}{c}\text { Parameter } \\
\text { Analisis }\end{array}$ & Satuan & Standar & Hasil Uji & Metode \\
\hline 1 & Kadar Air & $\%(a r)$ & CRM & 10,57 & $\begin{array}{c}\text { ASTM } \\
\text { D7582-10 }\end{array}$ \\
\hline 2 & Fixed Carbon & $\%(a d b)$ & CRM & 24,50 & $\begin{array}{c}\text { ASTM } \\
\text { D7582-10 }\end{array}$ \\
\hline 3 & Kadar Abu (Ash) & $\%(\mathrm{adb})$ & CRM & 1,85 & $\begin{array}{c}\text { ASTM } \\
\text { D7582-10 }\end{array}$ \\
\hline 4 & Volatile Matter & $\%(a d b)$ & CRM & 63,08 & $\begin{array}{c}\text { ASTM } \\
\text { D7582-10 }\end{array}$ \\
\hline
\end{tabular}

Sumber: Laboratorium Analisa Batubara Teknik Kimia Politeknik Negeri Sriwijaya, 2021

Tabel 7. Rasio Batubara : Kerosin Minyak Pelumas (1:1:2,5\%)

\begin{tabular}{clcccc}
\hline No & \multicolumn{1}{c}{$\begin{array}{c}\text { Parameter } \\
\text { Analisis }\end{array}$} & Satuan & Standar & Hasil Uji & Metode \\
\hline 1 & Kadar Air & $\%(\mathrm{ar})$ & CRM & 8,92 & ASTM \\
& & $\%(\mathrm{adb})$ & CRM & 31,06 & AST2-10 \\
2 & Fixed Carbon & $\%(\mathrm{adb})$ & CRM & 2,27 & D7582-10 \\
3 & Kadar Abu (Ash) & $\%(\mathrm{adb})$ & CRM & 57,76 & D7582-10 \\
& Volatile Matter & & ASTM \\
4 & & & & D7582-10 \\
\hline
\end{tabular}

Sumber: Laboratorium Analisa Batubara Teknik Kimia Politeknik Negeri Sriwijaya, 2021

Tabel 8. Hasil Analisa Proksimat dan Niali Kalor Batubara Sesudah Dilakukan UBC Berdasarkan Waktu Pemanasan

\begin{tabular}{ccccccc}
\hline No & $\begin{array}{c}\text { Waktu } \\
\text { Pemanasan } \\
(\text { Jam })\end{array}$ & $\begin{array}{c}\text { Kadar Air } \\
(\% \mathrm{adb})\end{array}$ & $\begin{array}{c}\text { Zat Terbang } \\
(\% \mathrm{adb})\end{array}$ & $\begin{array}{c}\text { Abu } \\
(\% \mathrm{adb})\end{array}$ & $\begin{array}{c}\text { Fixed Carbon } \\
(\% \mathrm{adb})\end{array}$ & $\begin{array}{c}\text { Nilai Kalor } \\
(\mathrm{cal} / \mathrm{gr})\end{array}$ \\
\hline 1 & 1,5 & 14,62 & 38,91 & 5.30 & 41.10 & 5838 \\
2 & 2 & 14,54 & 39,14 & 5,35 & 40.97 & 6210 \\
3 & 2,5 & 14,35 & 38,68 & 5,33 & 41,64 & 6590 \\
4 & 3 & 14,27 & 38,47 & 4,34 & 41,92 & 7271 \\
\hline
\end{tabular}

Sumber: Laboratorium Politeknik Negeri Sriwijaya, 2021

\subsection{Analisis Kadar Air (Inherent Moisture)}

Berdasarkan hasil analisa penelitian yang dilakukan didapatkan grafik hubungan rasio komposisi volume kerosin dan minyak pelumas terhadap kadar air dapat terlihat pada Gambar 12. 


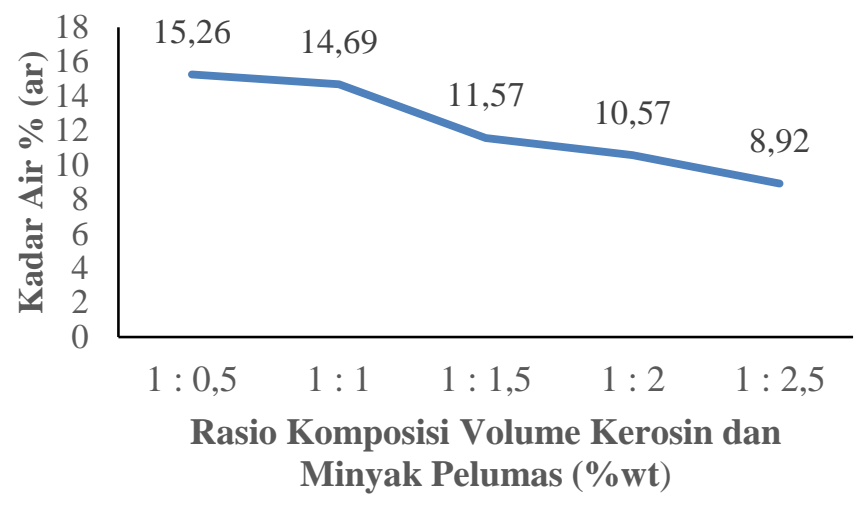

Gambar 12. Grafik Rasio Komposisi Volume Kerosin dan Minyak Pelumas Terhadap Kadar Air (Inherent Moisture) Setelah dilakukan UBC

Dari grafik diatas dapat dilihat terjadi penurunan dari kadar air batubara awal yang memiliki kadar air 19,58\% seiring dengan semakin besarnya rasio komposisi volume kerosin dan minyak pelumas. Perbedaan nilai inherent moisture produk UBC pada setiap rasio komposisi volume kerosin dan minyak pelumas berkaitan dengan banyaknya minyak pelumas (oli) yang masuk ke dalam pori-pori batubara dikarenakan pada saat proses pemanasan (Slurry Dewatering) berlangsung, air dalam pori-pori batubara keluar, sehingga kehilangan sejumlah massa bahan-bahan penyusun batubara melalui pori-pori, menyebabkan terjadinya kekosongan pori-pori tersebut. Dalam proses UBC, batubara dicampur kerosin dan oli kemudian dipanaskan pada tekanan dan temperatur yang relatif rendah. Dengan kerosin tersebut, maka pori-pori batubara yang terbuka disubtitusikan oleh oli dan menutup permukaan batubara sehingga air yang telah keluar tidak akan terserap kembali. Sehingga menyebabkan kadar air yang terdapat dalam batubara dapat menghilang atau berkurang.

Oleh sebab itu dibutuhkan oli sebagai stabilisator yang berfungsi menggantikan kekosongan pori-pori akibat kehilangan kadar air pada batubara tersebut kemudian minyak berat (minyak pelumas) akan teradsorpsi secara selektif di dalam pori-pori tersebutsehingga menutupi permukaan partikel batubara (terlapisi) oleh minyak residu yang mengakibatkan air yang keluar dari pori-pori tidak dapat kembali masuk (terserap) ke dalam batubara, sehingga semakin banyak volume minyak pelumas yang mengisi pori-pori batubara pada saat proses pemanasan maka semakin banyak inherent moisture yang telah keluar tidak dapat masuk kembali ke dalam pori-pori batubara, dan penambahan minyak pelumas dalam minyak tanah (kerosin) diperlukan untuk menjaga kestabilan kadar air bawaan batubara pasca proses. Sedangkan kerosin diperlukan sebagai media dalam proses.

\subsection{Analisis Fixed Carbon}

Ketiga komponen tersebut sangat memengaruhi kualitas atau kadar dari kalori suatu batubara, karena ketiga komponen tersebut merupakan komponen penyusun batubara yang saling mengisi satu sama lain, jika moisture besar maka coal matter dan mineral matter akan rendah begitupun berlaku bagi setiap komponen yang lain tinggi berarti komponen lainnya akan menjadi rendah.

Kadar karbon tertambat merupakan karbon yang tertinggal sesudah kandungan air dan zat terbangnya hilang. Dengan adanya pengeluaran kandungan air dan zat terbang maka karbon tertambat secara otomatis akan naik, sehingga makin tinggi kandungan karbonnya kelas batubara makin baik. Karbon tertambat menggambarkan sisa penguraian dari komponen organik batubara ditambah sedikit senyawa nitrogen, belerang, hidrogen, dan mungkin oksigen yang terserap atau bersatu secara kimiawi.

Dari hasil analisa dapat dilihat nilai kadar fixed carbon paling tinggi ialah rasio komposisi volume kerosin dan minyak pelumas $1: 1,5 \%$ sebesar $56,46 \%$ sedangkan nilai fixed carbon paling kecil ialah batubara rasio komposisi volume kerosin dan minyak pelumas 1:2\% sebesar 24,50\%. Tidak menentunya nilai fixed carbon ini dipengaruhi oleh temperatur pemanasan, nilai kadar air dan volatile matter karena semakin tingginya kadar air dan kadar volatille matter dapat menyebabkan menurun kadar fixed carbon. Adapun peningkatan dan penurunan kadar fixed carbon dapat dilihat pada Gambar 13.

Dari Gambar 13 dapat dilihat bahwa pada batubara terjadi peningkatan kadar karbon dari 43,84\% menjadi $56,46 \%$ kemudian menurun kembali menjadi $24,50 \%$. Hal ini disebabkan karena pada batubara rasio komposisi volume kerosin dan minyak pelumas 1:1:2\% dan 1:1:2,5\% memiliki nilai volatille matter yang tinggi. 


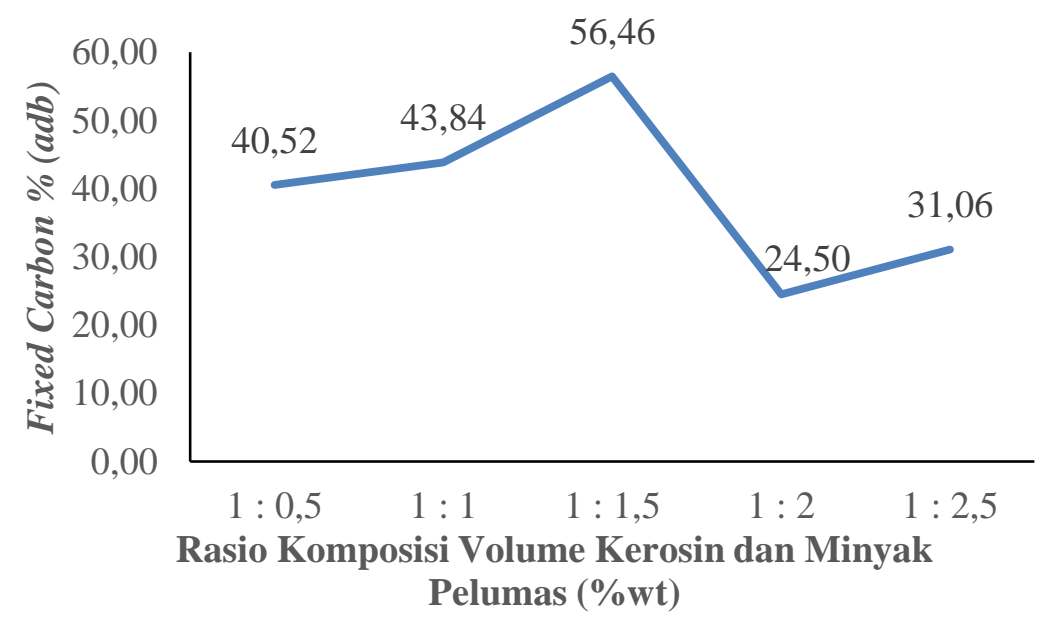

Gambar 13 Grafik Rasio Komposisi Volume Kerosin dan Minyak Pelumas Terhadap Kadar fixed carbon Batubara Setelah dilakukan Proses UBC

\subsection{Analisis Kadar Abu (Ash)}

Abu batubara adalah bagian dari sisa pembakaran batubara yang berbentuk partikel halus amorf dan abu tersebut merupakan bahan anorganik yang terbentuk dari perubahan bahan mineral (mineral matter) karena proses pembakaran. Kandungan abu akan terbawa bersama gas pembakaran melalui ruang bakar dan daerah konveksi dalam bentuk abu terbang atau abu dasar. Sekitar $20 \%$ dalam bentuk abu dasar dan $80 \%$ dalam bentuk abu terbang.

Dari hasil analisa didapatkan nilai kadar abu paling tinggi ialah pada rasio komposisi volume kerosin dan minyak pelumas 1:0,5\% sebesar 5,40\%. Sedangkan kadar abu paling rendah terdapat pada batubara dengan rasio komposisi volume kerosin dan minyak pelumas 1:2\% sebesar 1,85\%. Kecenderungan penurunan kadar abu pada ukuran batubara yang kecil disebabkan karena kandungan zat terbang yang tinggi. Seperti yang telah dibahas di atas bahwa kandungan zat terbang yang tinggi akan lebih mempercepat pembakaran karbon padatnya sehingga proses pembakaran terjadi lebih maksimal. Zat terbang yang diakibatkan dari banyaknya kerosin dan oli yang terserap menambah sifat spontaneous combustible pada batubara. Secara jelas penurunan kadar abu batubara yang dipengaruhi oleh rasio komposisi volume kerosin dan minyak pelumas dapat dilihat pada Gambar 14.

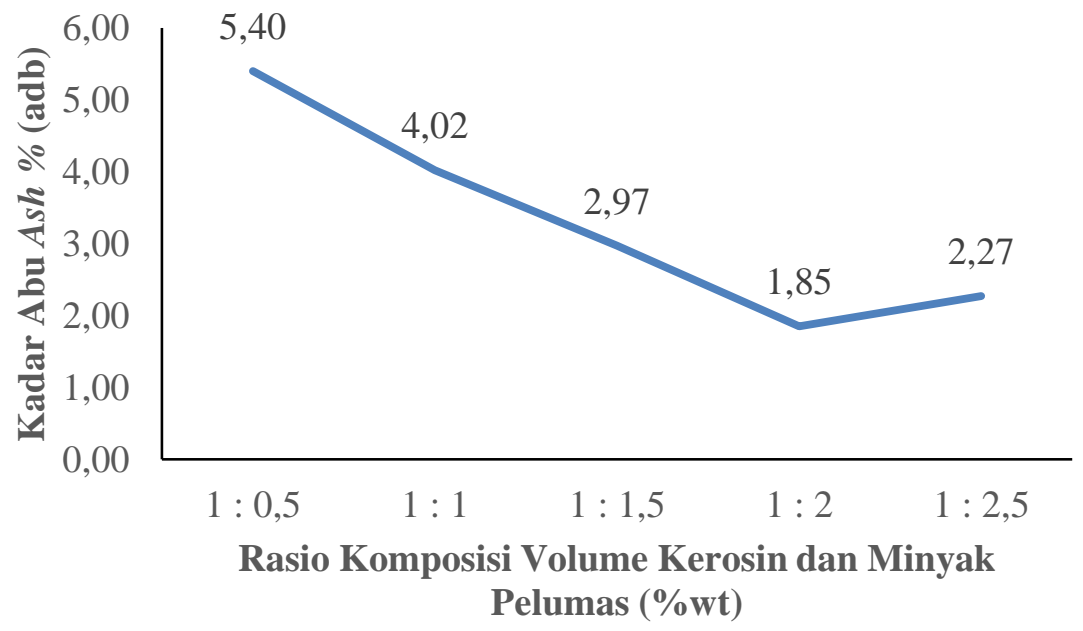

Gambar 14. Grafik Rasio Komposisi Volume Kerosin dan Minyak Pelumas Terhadap Kadar Abu (Ash) Batubara Setelah dilakukan Proses UBC

Grafik yang dihasilkan dari data yang didapat membentuk kurva yang cenderung menurun. Akan tetapi penurunan kandungan abu pada batubara dengan rasio komposisi volume kerosin dan minyak pelumas dari 1:0,5\% s.d 1:2,5\% tidak terjadi secara signifikan dengan ukuran batubara 60 mesh. Hal ini terlihat bahwa ukuran partikel batubara dan rasio kerosin: minyak pelumas tidak berpengaruh terlalu banyak terhadap kandungan abu produk hasil UBC. 


\subsection{Analisis Kadar Zat Terbang (Volatile Matter)}

Zat terbang terdiri dari gas-gas yang mudah terbakar seperti $\mathrm{H} 2$, $\mathrm{CO}$, dan metan serta uap-uap yang mengembun seperti tar, juga gas $\mathrm{CO} 2$ dan $\mathrm{H} 2 \mathrm{O}$. Pada pembakaran batubara, kandungan zat terbang yang tinggi akan lebih mempercepat pembakaran karbon padatnya dan sebaliknya zat terbang yang lebih rendah mempersulit proses pembakaran.

Kandungan zat terbang atau yang sering disebut dengan volatile matter dalam batubara ini mempengaruhi kesempumaan pembakaran dan intensitas api. Hal itu didasarkan pada rasio atau perbandingan antara kandungan karbon (fixed carbon) dengan zat terbang, yang disebut dengan rasio bahan bakar (fuel ratio). Semakin tinggi nilai fuel ratio maka jumlah karbon di dalam batubara yang tidak terbakar juga semakin banyak. Jika perbandingan tersebut nilainya lebih dari 1.2, maka pengapian akan kurang bagus sehingga mengakibatkan kecepatan pembakaran menurun. Pada pembakaran batubara, kandungan zat terbang yang tinggi akan lebih mempercepat pembakaran karbon padatnya dan sebaliknya zat terbang yang lebih rendah akan mempersulit proses pembakaran.

Dengan perbedaan rasio komposisi volume kerosin dan minyak pelumas untuk proses UBC, kadar zat terbang dalam produk mengalami peningkatan seiring dengan semakin besarnya rasio komposisi volume kerosin dan minyak pelumas. Dari hasil pengujian analisa kadar zat terbang terlihat nilai zat terbang (volatile matter) paling tinggi ialah sampel produk batubara dengan rasio komposisi volume kerosin dan minyak pelumas 1:2\% sebesar 63,08\%. Adapun peningkatan Volatile Matter dapat dilihat pada Gambar 15.

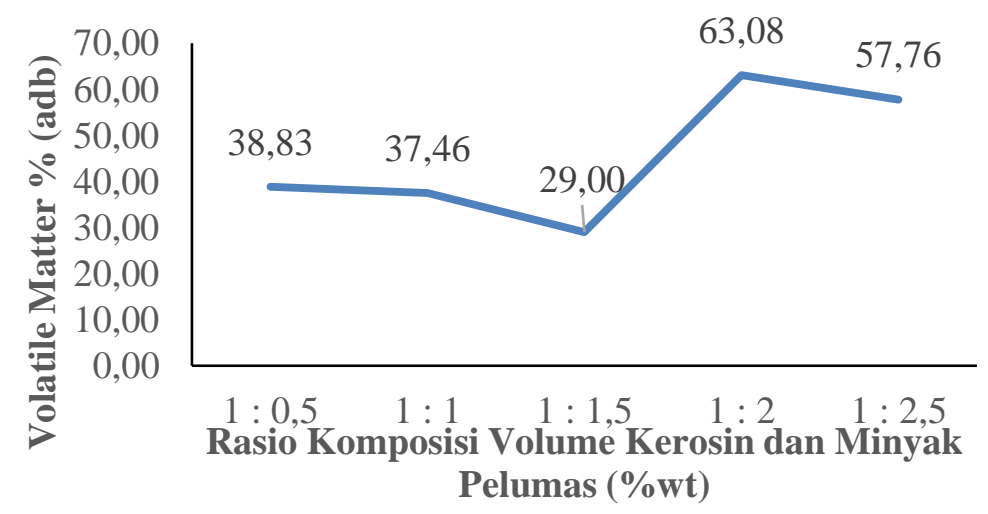

Gambar 15. Grafik Rasio Komposisi Volume Kerosin dan Minyak Pelumas Terhadap Kadar Zat Terbang

Batubara Setelah dilakukan Proses UBC

Dari Gambar 15 dapat dilihat peningkatan nilai volatille matter, hal ini disebabkan karena semakin besarnya rasio komposisi volume kerosin dan minyak pelumas yang digunakan dalam proses Slurry Dewatering maka semakin banyak pula molekul minyak pelumas dan kerosin yang teradsorbsi ke batubara sehingga pada saat penentuan zat terbang, residu tersebut terdeteksi sebagai zat terbang.

\subsection{Pengaruh Rasio Komposisi Volume Kerosin dan Minyak Pelumas Terhadap Nilai Kalor Batubara}

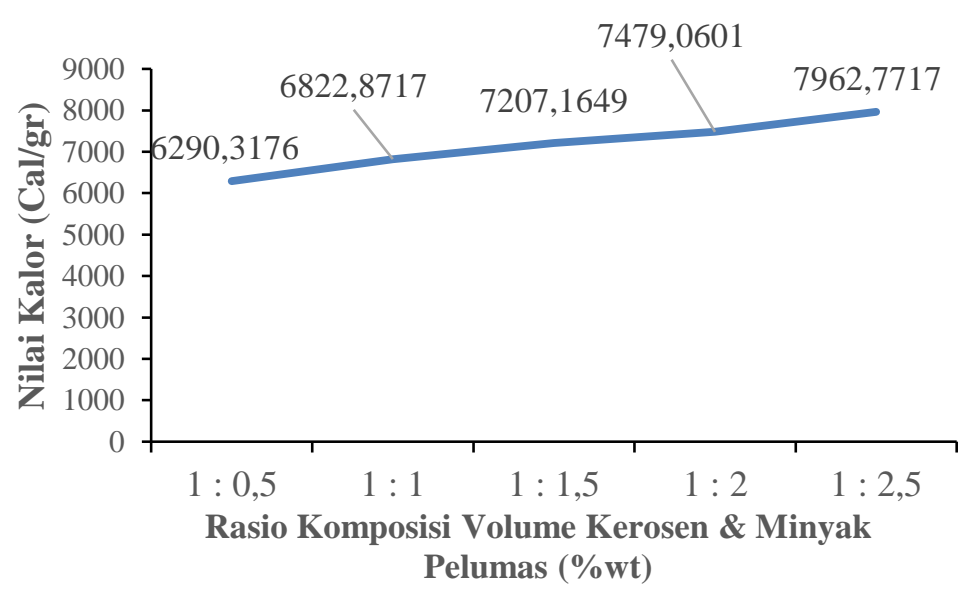

Gambar 16. Grafik Rasio Komposisi Volume Kerosin dan Minyak Pelumas Terhadap Nilai Kalor Batubara Setelah dilakukan Proses UBC 
Dari Grafik diatas dapat dianalisa bahwa terjadinya peningkatan nilai kalor pada batubara setiap penambahan rasio komposisi volume kerosin dan minyak pelumas dari berat sampel batubara $1: 1: 0,5 \%, 1: 1: 1 \%, 1: 1: 1,5 \%$, $1: 1: 2 \%, 1: 1: 2,5 \%$ (\%wt) dari berat sampel batubara. Adapun pengaruh kandungan moisture yang tinggi dapat menurunkan nilai kalor batubara. Apabila nilai moisture meningkat secara otomatis maka nilai kalori pun akan turun, sebaliknya apabila nilai moisture dapat dijaga atau diturunkan maka nilai kalor akan relative stabil bahkan akan meningkat

\subsection{Hubungan Pengaruh Inherent Moisture Terhadap Nilai Kalor Batubara}

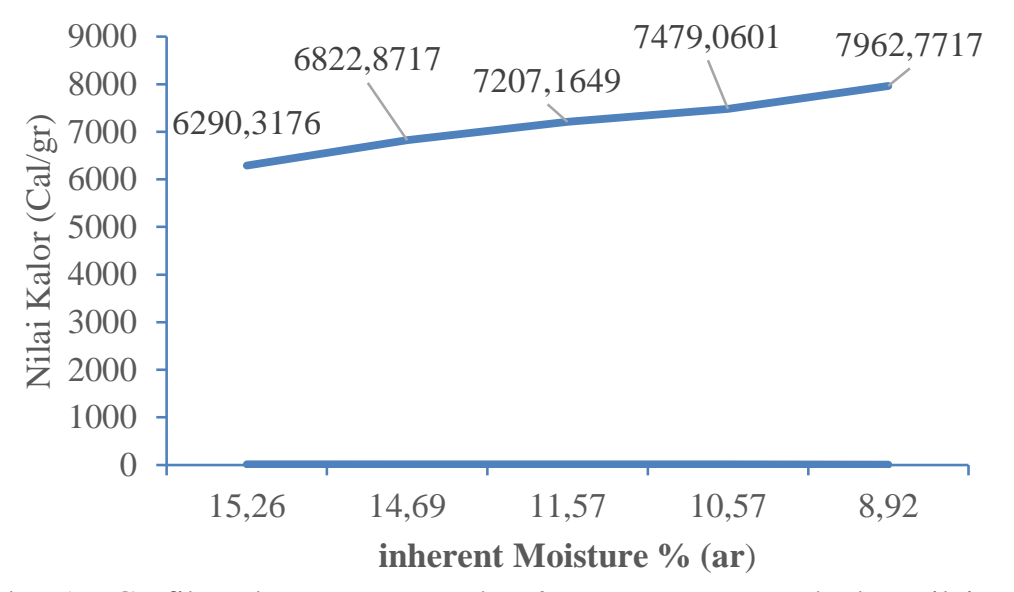

Gambar 17. Grafik Hubungan Pengaruh Inherent Moisture Terhadap Nilai Kalor

Berdasarkan gambar 17. dari hasil penelitian batubara dapat dianalisa batubara hasil upgrading semakin menurun seiring bertambah nya komposisi rasio volume kerosin dan minyak pelumas dengan perbandingan $1: 1$ : 2,5\% memiliki kadar air yang rendah 8,92\% (ar) dan peningkatan nilai kalor yang signifikan sebesar 7962,7717 $\mathrm{Cal} /$ gr. Sedangkan rasio batubara: kerosin : minyak pelumas $1: 1: 0,5 \%$ memiliki kadar air yang masih tinggi 15,26\% (ar) dan nilai kalor 6290,3176 Cal/gr. Dari hasil penelitian tersebut telah terjadi peningkatan baik nilai kalor dan penurunan kadar air (inherent moisture) pada batubara setelah dilakukan proses Upgrading Brown Coal (UBC). Peningkatan nilai kalor juga disebabkan karena dipengaruhi oleh komposisi volume minyak pelumas yang masuk ke dalam pori-pori batubara untuk mengisi kekosongan pori-pori akibat pengeluaran (penguapan) air bawaan dalam batubara, lama waktu pemanasan optimum yakni 2,5 jam akan menyebabkan semakin maksimalnya kadar air (proses penguapan air) yang keluar dari batubara dengan temperatur pemanasan yang konstan.. Dalam penurunan kadar air dan peningkatan nilai kalor juga dipengaruhi oleh temperatur pemanasan dimana semakin tingginya temperatur maka semakin kecil kadar air oleh sebab itu penelitian ini dilakukan pada temperatur pemanasan $200^{\circ} \mathrm{C}$. hal ini karena terjadinya proses penguapan yang optimum.. Selama proses pemanasan akan terjadi reaksi kimia yang menghasilkan produk gas atau cairan yang banyak berhubungan dengan sistem pori-pori batubara [4] sehingga dibutuhkan minyak pelumas sebagai stabilisator. Penggunaan minyak pelumas dikarenakan untuk mengatasi dalam pemakaian temperatur dan tekanan yang cukup rendah, pengeluaran tar belum sempurna, karenanya diperlukan zat aditif sebagai penutup permukaan batubara dan oli merupakan salah satu senyawa organik yang beberapa sifat kimianya mempunyai kesamaan dengan batubara. Lapisan minyak ini cukup kuat dan dapat menempel pada waktu yang cukup lama sehingga batubara dapat disimpan ditempat terbuka untuk jangka waktu yang cukup lama. Sehingga semakin kecil kadar air yang dihasilkan maka semakin besar peningkatan nilai kalori batubara

\section{KESIMPULAN}

Berdasarkan hasil penelitian yang telah dilakukan maka dapat disimpulkan bahwa kondisi optimal untuk mendapatkan nilai kalor yang tinggi dan kadar air yang sedikit yaitu pada waktu pemanasan 3 jam dengan rasio 1 : $1: 2,5 \%$ pada temperatur pemanasan $200{ }^{\circ} \mathrm{C}$ dan tekanan sebesar 3 dengan nilai kalor yang di dapat sebesar $7271,1656 \mathrm{cal} / \mathrm{gr}$ hingga 7962,7717 cal/gr sedangkan rasio komposisi volume kerosin dan minyak pelumas pada proses slurry dewatering untuk mereduksi kadar air dan meningkatkan nilai kalor yang paling optimal yaitu perbandingan batubara : kerosin : minyak pelumas $1: 1: 2,5 \%$ dengan nilai kalor sebesar 7962,7717 Cal/gr dan kadar air (inherent moisture) sebesar 8,92 \% (ar). Teknologi peningkatan nilai kalor batubara dengan metode Upgrading Brown Coal (UBC) dapat memperbaiki kualitas batubata peringkat rendah menjadi batubara peringkat sedang atau tinggi dengan rancangan alat yang telah memenuhi persyaratan proses upgrading batubara ini. 


\section{DAFTAR PUSTAKA}

[1] Indonesia, Dewan Energi, Outlook Energi Indonesia, Kementerian Sumber Daya dan Mineral, 2016.

[2] I. Rijwan, "Optimalisasi Proses Upgraded Brown Coal Kadar Air Tinggi," Puslitbang Tekmira, vol. V, 2011.

[3] T. Deguchi, T. Shigehisa, and K. Shimasaki, "Study on Upgraded Brown Coal Process for Indonesian Low Rank Coals," Proc. International Conference On Clean and Efficient Coal Technology in Power Generation, pp. 176-180, 1999.

[4] H. Hartiniati, M. Hanif, M. Tamura, S. Yanai, and T Shigehisa, "Feasibility Study on Coal Liquefaction Project in Kalimantan," UNTAD Journal, vol. IV, no. 2, 2008, doi: 10.29122/elk.v4i2.1531.

[5] A. Syamsuddin, "Studi Pengaruh Proses Carbontec Drying Terhadap Peningkatan Kualitas Batubara Peringkat Rendah," Tugas Sarjana Institut Teknologi Bandung, 1996.

[6] D. F. Umar, Suganal, H. Priyono, N. Nuroinah, "Uji Coba Peningkatan Kualitas Batubara Peringkat Rendah Dengan Proses UBC (Upgraded Brown Coal) Palimanan," Laporan Intern Puslitbang Teknologi Mineral dan Batubara, 2003.

[7] D. F. Umar, T. S. Kunrat, I. Rijawan, G. K. Hudaya, and L. Setiawan, "Persiapan Pembangunan UBC Demonstration Plant," Laporan Intern Puslitbang Teknologi Mineral dan Batubara, 2007.

[8] D. F. Umar, "Pengaruh Proses Upgrading terhadap Kualitas Batubara Bunyu," Seminar Rekayasa Kimia dan Proses, 2010.

[9] Yuliusman, W. P. Widodo, S. N. Yulianto, P. Yuda, "Preparasi Zeolit Alam Lampung Dengan Larutan Hf, HCL dan Kalsinasi Untuk Adsorpsi Gas CO," Prosiding Seminar Rekayasa Kimia dan Proses, 2010.

[11] T. Deguchi, T. Shigehisa, E. Makino, and Y. Otaka, "Proc. International Conference and Exhibitionon Clean and Efficient Coal Technology In Power Generation," Coal-Tech, 2002.

[12] T. Shigesa, "UBC oogata jisshou purojekuto," JCOAL Journal, vol. V, September 2006. 